\title{
Socio-demographic profile of different samples of Latin American rural extensionists
}

\author{
Perfil sociodemográfico de diferentes amostras de extensionistas rurais da América Latina
}

\author{
Fernando Landini ${ }^{\mathrm{I}}$ Vanina Bianqui ${ }^{\mathrm{II}}$
}

\section{ABSTRACT}

In order to design and implement public policies in the context of rural development, information tends to be gathered about family farming in different Latin American countries. In contrast, scarce attention has been given to the description of rural extensionists, who are the ones supporting family farming in the field. A cross-sectional investigation was conducted between 2010 and 2012 including surveys to rural extensions working in 10 different Latin American countries, this allowing for a preliminary description of the socio-demographic profile of the respondents. The samples were incidental ranging from 19 (Bolivia) to 220 (Argentina) subjects, this implying that they were not representative. Significant statistical differences were found with regards to the sex, age, experience, level of education and university degree of the samples pertaining to the different countries. In average, most extensionists are men (70.1\%), age 40.3 and have little more than 11 years of experience as extensionists. Brazilian practitioners surveyed are the oldest, most educated and experienced among the different samples. In general, most extensionists have a technical background and are agricultural engineers. The Uruguayan sample showed the highest percentage of extensionists coming from the area of social sciences.

Key words: socio-demographic profile; survey; rural extension; Latin American countries.

\section{RESUMO}

A fim de elaborar e implementar políticas públicas no contexto do desenvolvimento rural, é muito comum a coleta de informações sobre a distribuição e as características da agricultura familiar. Em contraste, tem sido dada pouca atenção à descrição sociodemográfica dos extensionistas rurais, que são os que apoiam a agricultura familiar no território. Entre 2010 e 2012, foi feita umtrabalho em que foram pesquisados extensionistas rurais que trabalham em 10 países latino-americanos diferentes, permitindo, assim, uma descrição preliminar do perfil sociodemográfico destes extensionistas. As amostras foram incidentais, variando de 19 indivíduos (Bolívia) a 220 (Argentina), implicando que elas não são representativas. Foram encontradas diferenças estatisticamente significativas no sexo, idade, experiência, nível de escolaridade e título academico dos extensionistas das amostras pertencentes aos diferentes países. Em média, a maioria dos extensionistas são homens (70,1\%), tem 40,3 anos de idade e tem pouco mais de 11 anos de experiência como extensionistas rurais. Os brasileiros pesquisados são os mais idosos, educados e experientes entre as diferentes amostras. Em geral, a maioria dos extensionistas têm formação técnica e são engenheiros agrícolas. Na amostra uruguaia, pode ser encontrado o maior percentual de extensionistas provenientes da área das ciências sociais.

Palavras-chave: perfíl sociodemográfico, enquete, extensão rural, países latino-americanos.

\section{INTRODUCTION}

To have relevant and organized information is fundamental for making decisions in the context of public policy. In the area of rural development, agrarian censuses play a key role. Within this vein, there is an important number of publications describing, characterizing, quantifying or exploring tendencies in the context of family agriculture or small farming in the Latin American subcontinent, many of them supported or written upon the request of national or international rural development institutions (Ministries of Agriculture, the Inter-American Institute for Cooperation on Agriculture or the Food and Agriculture Organization of the United Nations, among others).

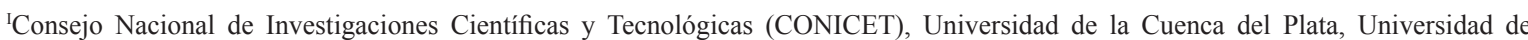
Buenos Aires (UBA), Gral. Juan Lavalle 2353, (C1052AAA), Buenos Aires, Argentina. E-mail: landini_fer@hotmail.com. Autor para correspondência.

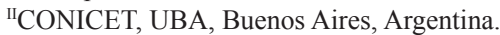


At a Latin American Level, for instance, CARMAGNANI (2008) analyzed the characteristics of family agriculture in most Latin American countries, based on national agrarian census; and MALETTA (2011) described its tendencies and future perspectives. At a national or sub-national level, Argentina and Brazil seem to stand out in terms of the levels of availability of academic literature. In Argentina, there are several institutional documents describing the distribution, importance and use of technology of peasants, small farmers or family farmers (SCHEINKERMAN et al., 2007; TSAKOUMAGKOS et al., 2000; TSAKOUMAGKOS et al., 2009). In Brazil, several papers compare the 1996 and the 2006 agrarian censuses. For example, GUANZIROLI et al. (2012) analyzed the general evolution of the family farming sector, and KAMIMURA et al. (2010) addressed the specific topic of the regional disequilibrium of profitability. Additionally, there is also literature describing and characterizing family farming and its evolution in many other countries (ECHENIQUE \& ROMERO, 2009; GARAY et al., 2010).

Nonetheless, despite the existence of multiple documents describing and characterizing family agriculture in Latin America and in different countries, nothing similar happens with regards to rural extension practitioners (perhaps with the only exception of the papers of LANDINI, 2013, in press, describing the rural extensionists' socio-demographic profile in Argentina and in Paraguay). In fact, in most Latin American countries, and in Latin America as a whole, it is unclear how many rural extensionists (or development agents) are working with family farmers and what their characteristics are, such as, for example, level of education, university degree or years of experience in their job. In order to address the issue of rural development, only describing and characterizing family farming is not enough. To design and implement public policies and development interventions aimed at the sector requires also having information about those supporting family agriculture in the field: the rural extensionists. A non-simplistic, systemic perspective not only needs information about the sector and of the reality to be intervened, but also about the intervention system itself. Thus, this investigation's objective will be to contribute to the description of the characteristics of Latin American rural extensionists.

\section{MATERIAL AND METHODS}

Between 2010 and 2012 a cross-sectional, exploratory investigation based on the implementation of a survey was conducted (MONTERO \& LEÓN, 2007), which allowed us to contribute to the statistical description of the socio-demographic profile of Latin American rural extensionists. The survey was sent via email to respondents working in 10 different countries. It included closed and open questions. In this paper, only the replies to the closed questions will be analyzed. These questions looked for information about the following variables: age, country, education (titles/degrees obtained and maximum completed level), sex and years of experience as rural extensionists. Information about the different samples is shown in table 1, including each case's size, the year(s) when they were collected and the institutions that supported the processes. When the institutions were more than three, it is referred to in table 1 as 'multiple institutions'. Additionally, in some cases, local researchers or professionals also helped to obtain the surveys, which is described as 'personal contacts'.

Given that Ciência Rural is a Brazilian journal and that there is no unified, public extension institution in Brazil, but instead many, highly diverse ones that make-up a part of the estate governments (THORNTON, 2006), it is important to clarify the specific origins of the Brazilian sample. Concretely, 31 are from Minas Gerais, 13 from Paraná, 4 from São Paulo, 2 from Rio de Janeiro, 1 from Espíritu Santo and 1 from Rondônia. This means that the majority of the sample is from the southeastern region of the country.

As a general procedure, in order to obtain completed surveys, national and/or local extension institutions, mostly public but also NGOs, were contacted. Where available, national, public extension institutions were preferred. If they did not exist in the country, did not support the research, or were unreachable, NGOs and/or personal contacts (local researchers or professionals previously known by the research group) were asked to help. In some cases, we obtained the rural extensionists' emails and sent the survey directly, but in most cases, institutional authorities forwarded our survey to them. Though in most cases and countries replies were sent directly to our email account, in some opportunities institutions gathered the answers and sent them to us all together. In general terms, rural extensionists who replied to the survey did it willingly, which implies that the sample was non-probabilistic incidental (TOMÁSSÁBADO, 2009). This leads to the fact that the results of this research cannot strictly be considered as a description of the Latin American rural extensionists' socio-demographic profile as a whole, but only of the sample gathered. Nonetheless, as it was argued in the introduction, the virtual absence of information in this 
Table 1 - General description of the samples.

\begin{tabular}{|c|c|c|c|}
\hline Country & $\mathrm{n}=$ & Year of the surveys & -------------------------------------------Support-------------------------------------- \\
\hline Argentina & 220 & $2010 \& 2011$ & $\begin{array}{l}\text { - Instituto Nacional de Tecnología Agropecuaria } \\
\text { - Subsecretaría de Agricultura Familiar }\end{array}$ \\
\hline Bolivia & 19 & 2010 to 2012 & - Multiple institutions and personal contacts \\
\hline Brazil & 52 & $2011 \& 2012$ & $\begin{array}{l}\text { - Empresa de Assistência Técnica e Extensão Rural from different } \\
\text { Brazilian states }\end{array}$ \\
\hline Chile & 41 & 2012 & $\begin{array}{l}\text { - Instituto de Investigaciones Agropecuarias } \\
\text { - Instituto Interamericano de Cooperación para la Agricultura sede Chile }\end{array}$ \\
\hline Ecuador & 74 & $2010 \& 2011$ & $\begin{array}{l}\text { - Ministerio de Agricultura, Ganadería, Acuacultura y Pesca } \\
\text { - Personal contacts }\end{array}$ \\
\hline El Salvador & 34 & 2010 & - Centro Nacional de Tecnología Agropecuaria y Forestal \\
\hline México & 60 & $2010 \& 2012$ & $\begin{array}{l}\text { - Secretaría de Agricultura, Ganadería, Desarrollo Rural, Pesca y } \\
\text { Alimentación } \\
\text { - Personal contacts }\end{array}$ \\
\hline Paraguay & 26 & 2011 & - Dirección de Extensión Agraria \\
\hline Peru & 31 & $2011 \& 2012$ & - Personal contacts \\
\hline Uruguay & 32 & 2012 & - Personal contacts \\
\hline Total & 589 & & \\
\hline
\end{tabular}

area makes these results relevant as they are a first reference or partial description of the topic of interest, which could help to design further investigations.

The analysis of the data collected was simple. Firstly, responses were incorporated into SPSS 17.0 software. After that, each relevant variable was described for each country using means or frequencies, depending on the case. Thirdly, non-parametric tests were used to test whether the observed differences were statistically significant. Kruskal Wallis test was used when age, experience and level of education (quantitative and ordinal variables) had to be compared among the different countries, Square-Chi when the association between two nominal variables had to be analyzed (in this case country and sex), and the Contingency Coefficient when Square-Chi was inappropriate because more than $20 \%$ of the cells had expected values of less than 5. Non-parametric statistics were utilized in all cases because normal distribution could not be assumed for the variables age and experience (KolmogorovSmirnov: $\mathrm{P}<0.001$ in these two cases).

\section{RESULTS AND DISCUSSION}

In table 2, the sex, age, experience in years in the area of rural extension and the maximum completed level of education for each country sample are described. In the case of level of education, means per country sample are shown, meaning: $0=$ none, $1=$ primary school, $2=$ secondary school, $3=$ nonuniversity technical studies, $4=$ university, $5=$ post graduation courses, $6=$ specialization, $7=$ master degree, $8=\mathrm{PhD}$. In table 3 the respondents' university degrees per country are mentioned.

Results show that, in the samples, extension staff is mainly male. In fact, the masculine personnel constitutes $70.1 \%$ and the female $30 \%$. This implies that, despite the importance of gender issues in the area of rural extension, it is possible that gender inequities occur in the very rural extension institutions themselves, as was clearly shown in the case of Paraguay where women, besides being fewer than men in terms of numbers within the extension staff, also occupy hierarchical positions 
Table 2 - General characteristics of rural extensionists per country sample.

\begin{tabular}{|c|c|c|c|c|c|}
\hline \multirow{2}{*}{ Country } & \multirow[b]{2}{*}{ Male } & \multirow[b]{2}{*}{ Female } & \multirow{2}{*}{ Age (mean) } & \multirow{2}{*}{ Experience (in years) } & \multirow{2}{*}{ Level of education } \\
\hline & & & & & \\
\hline Argentina & $65 \%$ & $35 \%$ & 42.2 & 11.3 & 4.5 \\
\hline Bolivia & $68.4 \%$ & $31.6 \%$ & 41.4 & 9.1 & 5.2 \\
\hline Brazil & $59.6 \%$ & $40.4 \%$ & 45.9 & 18.1 & 5.4 \\
\hline Chile & $46.3 \%$ & $53.7 \%$ & 40.1 & 10.7 & 4.5 \\
\hline Ecuador & $73.6 \%$ & $26.4 \%$ & 37 & 9.4 & 4.2 \\
\hline El Salvador & $97.1 \%$ & $2.9 \%$ & 41.3 & 13.9 & 3.8 \\
\hline México & $73.3 \%$ & $26.7 \%$ & 41.1 & 9.6 & 4.6 \\
\hline Paraguay & $72 \%$ & $28 \%$ & 34.4 & 10.1 & 4.2 \\
\hline Peru & $90.3 \%$ & $9.7 \%$ & 39.8 & 9.6 & 4.9 \\
\hline Uruguay & $54.8 \%$ & $45.2 \%$ & 40.3 & 9.5 & 4.4 \\
\hline Mean* & $70.1 \%$ & $30 \%$ & 40.3 & 11.1 & 4.6 \\
\hline
\end{tabular}

* General means average those of each country sample.

of lower status more often than would have been expected, given the percentage of women in the institution (LANDINI, 2013). Additionally, the sex of the extension personnel surveyed is not evenly distributed in all countries $\left(\chi^{2}=36.3(9), \mathrm{p}<.001\right)$. In the samples of countries such as El Salvador and Peru, male extensionists represent more than $90 \%$, while in others such as in the Chilean, Uruguayan and Brazilian samples, percentages per sex are more balanced. The case of the Chilean sample stands out because it is the only one wherein the number of women is greater than of men, which raises questions with regards to the historical reasons for this as well as to how gender relations work in that context.

The average age of the rural extensionists pertaining to the different samples is 40.3 years old. In this case, statistically relevant differences seem to exist among the different samples (Kruskal Wallis Test: $\left.\chi^{2}=40.5(9), \mathrm{P}<0.001\right)$. This fact could be highly dependent on the different institutional requirements placed on becoming an extensionist in each case, as will be mentioned further on in the case of Paraguay. It is important to note that these differences may also exist within each national sample, given that the different institutions included in each sample could have different requirements for hiring personnel, and the very institutions, in turn, could have varying standards for different positions. Thus, institutional requirements should be acknowledged as an underlying, relevant variable that could be influencing some of the following results, but which will not be taken into consideration unless enough information is available to do so.

As was mentioned previously, the average age of the rural extensionists pertaining to the different samples is 40.3 years old. Despite most country samples being located between the mean $+/-2$ years, three of them stand out. The Brazilian sample has the oldest rural extensionists of the different country samples, which could be suggesting, besides potentially different requirements for recruitment, that the number of new personnel being hired is not equal to the number of those leaving the institution due to retirement or other reasons. On the contrary, the samples from Paraguay and Ecuador have the youngest extension staff. With regards to the Paraguayan sample, it could be related to the fact that extensionists there tend to enter the Direction of Agrarian Extension [Dirección de Extensión Agraria] soon after finishing secondary school. Thus, the youngest extensionists in Paraguay in our sample are 19 years old, while in the rest of the samples they are no younger than 22 (in Brazil the youngest is 25 y.o.). It has been argued that rural extension is 'returning' to Latin America (ALEMANY et al., 2007), an interpretation that seems to be supported with facts in the case of Argentina and Paraguay (LANDINI, 2013 , in press), if analyzed in terms of the increment of extension personnel, but not in others such as Brazil, where the extensionists from our sample are clearly older than the rest, this potentially suggesting that few new extensionists are being incorporated.

With regards to the experience of the surveyed Latin American rural extensionists, there are also significant statistical differences among the country samples (Kruskal Wallis Test: $\chi^{2}=47.1(9)$, $\mathrm{P}<0.001)$. In this respect the Brazilian extensionists surveyed also stand out due to an average of 18.1 years of experience against a general mean of 11.1. Clearly, the Brazilian sample is the most experienced when compared with the other samples per country, 
which is valuable in the sense of having developed capacities to perform fruitfully in the field, but is also an indicator that could support the idea of the progressive aging of Brazilian rural extensionists. Also Salvadorian and Argentine samples have, in average, more experience than the mean, while the rest of the countries have less, but these differences do not stand out. An interesting question raised at this point is what the best average of extension experience is for an extension institution, given that lower figures could imply an inexperienced staff but higher ones the lack of generational turnover.

The level of education is also of importance when analyzing extension practice, given it is related to the practitioners' expert knowledge as well as to the extension approach they use (LANDINI et al., in press). As it happened with the other addressed variables, the surveyed extensionists' level of education is also related to the variable country (Kruskal Wallis Test: $\chi^{2}=52.6(9), \mathrm{P}<0.001$ ), this also being highly dependent on what each institution deems as a requirement in order to be hired as an extensionist. When analyzing the data, the Brazilian and Peruvian rural extensionists surveyed seem to have a higher level of education than the rest. In the Brazilian sample this could be related to them being the most experienced, which could have provided them with more opportunities to study while in their position, as was shown in Argentina where the more experienced an extensionist is, the more educated he tends to be (LANDINI, in press). Nevertheless, more information is required to support this argument. Regarding the Peruvian sample, and considering that most surveyed practitioners work in NGOs and not in the government, it is possible that only those with more studies had the possibility to work in the private sector, which could potentially pay higher salaries, but there is no evidence to support this possibility. At the other end is the Salvadorian sample, whose rural extensionists tend to have the lowest level of education when compared with the rest. In fact, it is the only country wherein the average is less than a university education.

Table 3 shows the different university degrees of the respondents, which are statistically related to the country wherein they work and live (Contingency Coefficient $=.53, \mathrm{P}<0.001)$. As a general result, we can see that most rural extensionists surveyed are agrarian engineers (63.3\%), almost 2 out of 3, with peaks existing in the samples of El Salvador (with more than $95 \%$ of those with university degree), Chile (78.1\%) and Argentina $(71.1 \%)$. Veterinarians and zootechnicians seem to be the most common in the Mexican sample, perhaps due to its origin or to the importance of husbandry in Mexico in comparison to other agrarian activities. The Uruguayan sample is particularly interesting with regards to the percentage of social scientists working in rural extension, given that this shapes (and is an example of) the institutional approach to rural extension. While the general average presence of practitioners from the area of social sciences is $7.8 \%$ out of those with a university degree in our samples, in Uruguay they represent $37.9 \%$ (the Uruguayan case is the only one with more than $12.5 \%$, which makes the percentage more striking). This makes Uruguay a particularly interesting place to study the impact of social scientists working in rural extension, given that it seems to represent a special case in Latin America with regards to this point. On the other hand, there are

Table 3 - University degree of rural extensionists per country sample.

\begin{tabular}{|c|c|c|c|c|c|}
\hline \multirow{2}{*}{ Country } & \multirow{2}{*}{ Without university degree } & \multicolumn{4}{|c|}{--------------------------------------With university degree* } \\
\hline & & Agrarian engineers & Veterinarians/ zootechnicians & Social sciences & Others \\
\hline Argentina & $15.2 \%$ & $71.1 \%$ & $10.4 \%$ & $9.3 \%$ & $9.3 \%$ \\
\hline Brazil & $14.6 \%$ & $60 \%$ & $8.6 \%$ & $11.4 \%$ & $20 \%$ \\
\hline Bolivia & $5.9 \%$ & $68.8 \%$ & $6.3 \%$ & $12.5 \%$ & $12.5 \%$ \\
\hline Chile & $11.1 \%$ & $78.1 \%$ & $9.4 \%$ & $0 \%$ & $12.5 \%$ \\
\hline Ecuador & $9.7 \%$ & $66.2 \%$ & $24.6 \%$ & $0 \%$ & $9.2 \%$ \\
\hline El Salvador & $22.6 \%$ & $95.8 \%$ & $0 \%$ & $0 \%$ & $4.2 \%$ \\
\hline México & $8.2 \%$ & $17.8 \%$ & $57.8 \%$ & $6.7 \%$ & $17.8 \%$ \\
\hline Paraguay & $39.1 \%$ & $57.1 \%$ & $14.3 \%$ & $0 \%$ & $28.6 \%$ \\
\hline Peru & $6.9 \%$ & $63 \%$ & $22.2 \%$ & $0 \%$ & $14.8 \%$ \\
\hline Uruguay & $6.5 \%$ & $55.2 \%$ & $6.9 \%$ & $37.9 \%$ & $0 \%$ \\
\hline Mean & $14 \%$ & $63.3 \%$ & $16 \%$ & $7.8 \%$ & $12.9 \%$ \\
\hline
\end{tabular}

* Percentages referring to extensionists with university degree exclude those without it when calculating the figures. 
several cases in which there are no social scientists, such as in the Chilean, Ecuadorian, Salvadorian, Paraguayan and Peruvian samples. The implications of this are relevant, given that it could be suggesting that extension practice in those contexts is being seen exclusively as a technology transfer process and not as a complex social process, an approach heavily criticized by many scholars (LEEUWIS, 2004; MACHADO et al., 2006) but still being implemented.

\section{CONCLUSION}

This investigation has reached many conclusions, suggesting in all cases the need for further research in different topics, particularly because of the fact that the samples analyzed are not representative. This implies, as it was argued previously, that results strictly refer to the samples gathered and not to all Latin American rural extensionists. Nonetheless, the scarce descriptive available information about these rural practitioners makes these results interesting topics to use as a guide for future investigations.

Firstly, this research suggests that most Latin American extensionists seem to be men, highlighting the need for reflection upon gender equity inside extension institutions as a way of being able to contribute to gender equity in the field at large. The case of the Chilean sample is particularly interesting, given that it is the only case wherein there are more women extensionists than men.

In terms of age, experience and level of education, the Brazilian sample stands out, because they are the oldest and the most experienced and educated rural extensionists when compared with the other samples. The implications of this are unclear, but could be suggesting the lack of renewal of the extension staff, a negative issue hidden behind positive indicators. On the other hand, another potentially interesting topic for further research is the reasons for the two 'youngest' samples, Ecuador and Paraguay. Could it be suggesting the opposite, in this case a recent increase in the extension staff?

As was expected, most extensionists in our samples are agrarian engineers. In the context of science becoming more interdisciplinary it seems, at least, in a sense, old fashioned, given that an integrated approach calls for the interaction of different scientific perspectives. Additionally, it could also be suggesting the presence of a traditional transfer of technology approach to extension practice in their institutions. In this regard, the Uruguayan sample stands out as an interesting case, given that the highest percentage of staff from the area of social sciences was found there, which invites for further study of the Uruguayan case in order to understand its specificities. On the other hand, the lack of personnel from the social sciences in several countries also suggest the need to analyze the extension approach in those contexts, perhaps it being too technically oriented. All in all, this investigation has reached many partial and preliminary results, which could thus guide more focused studies.

\section{REFERENCES}

ALEMANY, C.; et al. Vuelve la extensión rural? Reflexiones y propuestas agroecológicas vinculadas con el retorno y fortalecimiento de la extensión rural en América Latina. Realidad Económica, n.227, p.52-74, 2007.

CARMAGNANI, M. La agricultura familiar en América Latina. Problemas del Desarrollo, v.39, n.153, p.11-56, 2008. Available from: <http:/www.revistas.unam.mx/index.php/pde/article/ download/7720/7195>. Accessed: Nov. 27, 2009.

ECHENIQUE, J.; ROMERO, L. Evolución de la agricultura familiar en Chile en el período 1997-2007. Santiago de Chile: FAO, 2009. 122p.

GARAY, L.J.; et al. Impactos del TLC con Estados Unidos sobre la economía campesina en Colombia. Santiago de Chile: ILSA, 2010. 178p.

GUANZIROLI, C.E. et al. Dez anos de evolução da agricultura familiar no Brasil: (1996 e 2006). Revista de Economia e Sociologia Rural, v.50, n.2, p.351-370, 2012. Available from: <http://www.scielo.br/scielo.php?pid=S010320032012000200009\&script=sci_arttext $>$. Accessed: Apr. 19, 2013. doi: 10.1590/S0103-20032012000200009.

KAMIMURA, A. et al. A agricultura familiar no Brasil: um retrato do desequilíbrio regional. Interações, v.11, n.2, p.217-223, 2010. Available from: <http://www.scielo.br/scielo.php?pid=S151870122010000200010\&script=sci arttext $>$. Accessed: Apr. 18, 2013. doi: 10.1590/S1518-70122010000200010.

LANDINI, F.P. Perfil de los extensionistas de la dirección de extensión agraria. Revista de Investigación Agraria, v.15, n.1, p.39-46, 2013.

LANDINI, F.P. Perfil de los extensionistas rurales argentinos del sistema público. Mundo Agrario, in press.

LANDINI, F.P. et al. Evaluación de un proceso de capacitación para extensionistas rurales implementado en Paraguay. Revista de Economia e Sociologia Rural, in press.

LEEUWIS, C. Communication for rural innovation. Rethinking agricultural extension. Oxford: Blackwell, 2004. 412p.

MACHADO, J. et al. Estilos de relacionamento entre extensionistas e produtores: desde uma concepçao bancária até o 'empowerment'. Ciência Rural, v.36, n.2, p.641-647, 2006. Available from: $<$ http://www.scielo.br/pdf/cr/v36n2/a44v36n2.pdf $>$. Accessed: Mar. 21, 2010. doi: 10.1590/S0103-84782006000200044.

MALETTA H. Tendencias y perspectivas de la agricultura familiar en América Latina. Santiago de Chile: Centro Latinoamericano para el Desarrollo Rural, 2011. 33p. 
MONTERO, I.; LEÓN, O. A guide for naming research studies in psychology. International Journal of Clinical and Health Psychology, v.7, n.3, p.847-862, 2007. Available from: <http://www. redalyc.org/articulo.oa?id=33770318>. Accessed: Feb. 03, 2012.

SCHEINKERMAN, E. et al. Los pequeños productores en la República Argentina: importancia en la producción agropecuaria $\mathrm{y}$ en el empleo en base al censo nacional agropecuario 2002. Buenos Aires: Secretaría Agricultura, Ganadería, Pesca y Alimentos, Dirección de Desarrollo Agropecuario, 2007. 127p.

THORNTON, R. Os '90 e o novo século nos sistemas de extenão rural e transferência de tecnologia públicos no MERCOSUL. Anguil, Argentina: INTA, 2006. 406p.
TOMÁS-SÁBADO, J. Fundamentos de bioestadística y análisis de datos para enfermería. Barcelona: Universidad Autónoma de Barcelona, 2009. 146p.

TSAKOUMAGKOS, P. et al. Campesinos y pequeños productores en las regiones agroeconómicas de Argentina Buenos Aires: Ministerio de Economía. Secretaría de Agricultura, Ganadería, Pesca y Alimentos, 2000. 62p.

TSAKOUMAGKOS, P. et al. Tecnología y pequeña producción agropecuaria en la Argentina. Una caracterización basada en el Censo Nacional Agropecuario 2002 y en estudios de caso. Buenos Aires: Ministerio de Agricultura, Ganadería y Pesca, 2009. 335p. 